\title{
Effect of Peppermint and Multi-enzyme Supplementation on the Carcass Characteristics in the Broiler Chickens
}

\author{
Amit Kumar Lavania*, Sheela Choudhary, Anurag Pandey, Manju, Dharmendra \\ Chharang, Khushiram Yadav and Vijay Prakash Saini
}

\author{
Department of Animal Nutrition, Post Graduate Institute of Veterinary Education and \\ Research, Jamdoli, Jaipur-302031 (Rajasthan), India
}

*Corresponding author

\author{
A B S T R A C T
}

\begin{tabular}{|l|}
\hline K e y w o r d s \\
$\begin{array}{l}\text { Broiler, Carcass, } \\
\text { Multi-enzyme, } \\
\text { Peppermint }\end{array}$ \\
\hline Article Info \\
\hline $\begin{array}{l}\text { Accepted: } \\
\text { 07 August } 2020 \\
\text { Available Online: } \\
\text { 10 September } 2020\end{array}$ \\
\hline
\end{tabular}

The present study was conducted in broiler chickens to investigate the effect of Peppermint (Mentha arvensis) and multi-enzyme on the carcass characteristics of broiler chickens. The treatment groups consist of control group $\left(\mathrm{G}_{1}\right)$ fed only with nonsupplemented basal diet, group $\mathrm{G}_{2}$ was supplemented with $0.5 \%$ peppermint leaf powder, group $\mathrm{G}_{3}$ with $1 \%$ Peppermint leaf powder, group $\mathrm{G}_{4}$ with $0.05 \%$ multi-enzyme, group $\mathrm{G}_{5}$ with $0.5 \%$ peppermint leaf powder $+0.05 \%$ multi-enzyme and group $\mathrm{G}_{6}$ was supplemented with $1 \%$ Peppermint leaf powder $+0.05 \%$ multi-enzyme in basal feed. One broiler from each replicate was sacrificed at the end of trial to estimate the different carcass characteristics parameters. The supplementation of peppermint and multi-enzyme alone and in combination showed significantly $(\mathrm{P}<0.05)$ highest dressed and gizzard weightin $\mathrm{G}_{5}$ and $\mathrm{G}_{6}$ and lowest was observed in $\mathrm{G}_{1}$ group. Whereas, dietary inclusion of peppermint and multi-enzyme alone and in combination had no weight of heart, liver and giblet and eviscerated weight in broiler birds. It is concluded that the use of peppermint at 0.5 and $1.0 \%$ and multi-enzyme at $0.05 \%$ levels and their combination improved the carcass weight and other carcass traits in the broiler chickens.

\section{Introduction}

Poultry industry is very important sector that provides the cheapest protein source for human consumption within the shortest production period. Poultry industry is highly dependent on the feed price because feed costs amount to $60-70 \%$ of poultry production costs. The science of nutrition involves providing a balance of nutrients that best meets the poultry needs for growth, maintenance and meat production. In the modern feeding practices, feed additives are assuming a position of prime importance in poultry nutrition. The beneficial effects on health status, growth performance as well as nutrient utilization are mainly the reasons, why the feed additives are widely used. Feed additives are generally used to improve feed intake and to increase the growth rate in broilers (Fadlalla et al., 2010; Bali et al., 2011 and Abouelfetouh et al., 2012). Today, throughout the world, the use of antibiotics as growth promoters in animal nutrition has 
become undesirable due to the appearance of residues and resistant strain of bacteria.

The World Health Organization has recognized antibiotic resistance as a major and a growing problem related to public health in both human and animal medicine. The alternative measure to overcome the problem of antibiotic resistance might be the use of phytochemicals and natural products (Reverter et al., 2014). Feed additives derived from plants, also called phytogenic or phytobiotic or botanicals can be included in animal feeds. Scientific in vitro and in vivo studies have variously claimed that medicinal plants, used as either the whole plant or their leaves, seeds, essential oils, and active components, have antioxidant, antimicrobial, hypo-cholesteremic, and immune stimulating properties (Brenes and Roura, 2010) which may be beneficial to enhance poultry performance and meat quality. The impact of phytogenics on the intestinal microbiota is considered essential for the biological effects; however, the exact mode of action is still not clear (Hafeez et al., 2016).

\section{Peppermint}

Menthaarvensis belongs to the family Lamiaceaea, locally known as Pudina (Khan and Khatoon, 2008). It is distributed throughout the Western Himalayas and cultivated throughout the world. It is an erect aromatic herb that grows up to $60 \mathrm{~cm}$ in height with suckers; the stem is cylindrical and the leaves are simple and opposing type (Londonkar and Poddar, 2009). Mint is widely used in herbal medicine and believed to be beneficial as an immunity enhancer (Nanekarani et al., 2012). The mint plant has been reported to contain many active ingredients such as menthol (40-50\%) (Malik et al., 2012), carvone (67.3\%), limonene (13.5\%), 1, 8- cineole (5.4\%), linalool (2.8 $\%)$, menthone $(2.9 \%)$, and isomethone (1.2
\%) (Younis et al., 2004) which provide positive effects on health and productivity (Ghazaghi et al., 2014). The main medicinal action of the leaves and flowers of the mint depend on the abundant menthol which is the main phenolic component having antibacterial activity.

\section{Multi-Enzyme}

Enzymes are proteins that act as catalysts within living cells. Catalysts increase the rate at which chemical reactions occur without being consumed or permanently altered themselves. Poultry do not have enzyme to break down fiber completely and need exogenous enzymes in feed to aid digestion. A corn-based meal diet, which supplies the majority of the energy for broilers, is recommended worldwide as the most common broiler feed. Supplemental exogenous carbohydrases and phytases can hydrolyze NSP (Selle et al., 2009; Wang et al., 2009) and phytate (Applegate et al., 2003; Leytem et al., 2007), respectively, in broiler diets, thereby improving nutrient utilization and performance. Advances in enzyme biotechnology and knowledge of substrates have led to the development of non-starch polysaccharide (NSP) degrading enzymes, such as glucanase and xylanase, which are capable of improving metabolizable energy (ME) of viscous grains, such as wheat and barley. Numerous studies of exogenous enzyme supplementation in broiler diets have been conducted, and improvements of the performance of broiler chicks and nutrient availability have been well documented. Addition of enzymes to diets can help to eliminate the effects of anti-nutritional factors and improve the utilization of dietary energy and amino acids, resulting in improved performance of chickens (Zhou et al., 2009). Further, the supplementation of enzyme in poultry diets has been reported to having beneficial effect on gut morphology and thus 
improving absorption of nutrients (Qureshi et al., 2016).

Keeping the aforesaid facts in view, the present investigation was planned to study the effect of supplementation of peppermint (Mentha arvensis) and multi-enzyme alone and in combination on carcass characteristics in broiler chickens.

\section{Materials and Methods}

The experiment was conducted at the Livestock farm complex Post Graduate Institute of Veterinary Education and Research, Jamdoli, Jaipur, Rajasthan, India. The experiment was conducted in the month of July and August 2019 for the period of 35 days, for this experiment a total of Two hundred and forty (240) day-old, unsexed, apparently healthy broiler chicks (Cobb-85 strain) procured from a commercial supplier were used in the present experiment. All the chicks were individually weighed and randomly divided into six groups of 40 chicks each having almost similar average body weight. Each group of 40 chicks was further subdivided into four replicates having 10 chicks in each replicate. Routine vaccination against Ranikhet disease (V.H strain) and Infectious Bursal Disease was carried out on the $7^{\text {th }}$ and $14^{\text {th }}$ day of procurement of chicks, respectively. Dry sawdust was used as bedding material. Identical standard managemental practices regarding feeding, watering and disease control etc. were followed for each group during entire course of study. The experimental design has been shown in Table 1.

\section{Experimental feed and feeding schedule}

The ISO certified basal feed in the form of broiler starter and broiler finisher was procured as per the BIS (1992) from commercial supplier. The required quantities of the feed supplements i.e. peppermint
(Mentha arvensis) and multi-enzyme for formulations of experimental diets were also procured from the local market. Peppermint (Mentha arvensis) is utilized as a medicinal herb worldwide. Good quality peppermint leaves were procured in required quantity. The leaves were then sun-dried and ground to pass through $1 \mathrm{~mm}$ sieve and were stored in air tight plastic containers for further use. The commercially available multi-enzyme formulation "Multi-enzyme" procured from "Meteoric Biopharmaceuticals Pvt. Ltd.". Ahmedabad, gujarat.

\section{Carcass parameters}

At the end of trial, one bird from each replicate having body weight close to the group average was selected for estimation of carcass characteristics. The selected birds were weighed individually and allowed to fast for 12 hour to empty gut contents before sacrifice. The broilers were sacrificed as per standard procedure (Panda, 1995) by severing the occipito-atlantal joint and allowed to bleed completely. The birds were defeathered in defeathering machine after scalding and carcasses were eviscerated to measure various parameters of carcass.

\section{Carcasses yield / dressed weight}

Carcasses yield/dressed weight was calculated as follows:

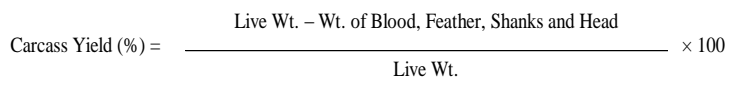

\section{Eviscerated weight}

The dressed birds were eviscerated by giving a median cut in the abdomen and removing the crop, gullet, trachea and viscera. The lungs were scrapped off. Heart, liver, pancreas, spleen and gizzard were separated from GI tract. The giblets (heart, liver and 
gizzard) were cleaned and retained along with the carcass to record eviscerated weight and expressed as percentage of pre-slaughter weight.

Eviscerated Wt. $(\%)=\frac{\text { Dressed Wt. }- \text { Wt. of Viscera Except Giblet }}{\text { Live wt. }} \times 100$

\section{Weight of giblets}

The weight of giblets (gizzard, heart and liver) was recorded individually after removal of all the attachments with the help of electronic balance.

\section{Statistical analysis}

The experimental data were subjected to statistical analysis (SPSS Ver. 24.0) using one way analysis of variance as described by Snedecor and Cochran (2004) to test for significant variation between treatment groups. Probabilities values of less than 0.05 $(\mathrm{P}<0.05)$ were considered significant. Comparison of mean values was carried out by Duncan's Multiple Range Test (Duncan, 1955). The results were interpreted and expressed as means \pm SEM.

\section{Results and Discussion}

\section{Carcass evaluation}

\section{Dressed and eviscerated weight}

The mean values of dressed weight and eviscerated weight (percent) of broiler chickens in different treatment groups are presented in the Table 2.

The mean per cent of dressed weight was significantly $(\mathrm{P}<0.05)$ highest in $\mathrm{G} 5$ followed by $\mathrm{G}_{6}, \mathrm{G}_{4}, \mathrm{G}_{3}, \mathrm{G}_{1}$ and least weight was observed in $\mathrm{G}_{2}$ groups, respectively whereas, there was no significant difference was observed in $G_{1}$, $\mathrm{G}_{2}$ and $\mathrm{G}_{3}$ groups.
The supplementation of different levels of peppermint (Mentha arvensis) and multienzyme on eviscerated weight was nonsignificant among the treatment groups. The results are in agreement with Galib (2010) who reported that dietary treatment group $0.5 \%$ and $1 \%$ peppermint exhibit a significant increase in dressing per cent compare with control. This result also agree well with the Durrani et al., (2008) who revealed that mean dressing percentage of broilers are high in Habek mint supplemented group. In contrary to present finding, Khursheed et al., (2017) revealed non-significant $(\mathrm{P}>0.05)$ difference in dressing percentage on supplementation of mint. Similarly, Abdel-Wareth et al., (2019) revealed that inclusion of different concentrations of peppermint leaves or menthol levels had no effect $(\mathrm{P}>0.05)$ on the relative weights of dressing percent. In agreement to the result of eviscerated weight of carcass, Khempaka et al., (2013) revealed that the percentage of eviscerated carcasses of broilers fed DPM were similar to the control and antibiotic supplementation diets.

The result of enzyme supplementation showed non-significant difference in dressed weight which was in accordance to finding of Bharathidhasan et al., (2009) who reported non-significant difference in carcass weight of broilers supplemented with $0.05 \%$ multienzymes in comparison to the control. Zakaria et al., (2010) also showed non-significant (P>0.05) effects on whole carcass weight when enzymes were added in broiler diets. Contrary to this, Khan et al., (2006) and Hajati (2010) reported that addition of enzyme in diets of broiler chicken significantly increased the carcass weight. Bansal et al., (2012) revealed that enzyme supplementation showed significant $(\mathrm{P}<0.05)$ difference on dressing percentage.

Nizamuddin et al., (2013) reported that values of dressing percentage was significantly 
$(\mathrm{P}<0.05)$ higher in dietary enzyme treated groups. Further the combination of peppermint and multi-enzyme showed significant difference, which is not in accordance with finding of Khursheed et al.,
(2017) who reported non-significant $(\mathrm{P}>0.05)$ difference in dressing percentage on supplementation of enzyme treated mint leaves to broiler chicken.

Table.1 Experimental feeds offered to broiler chicks in different treatment groups

\begin{tabular}{|c|c|c|c|}
\hline \multicolumn{2}{|c|}{$\begin{array}{l}\text { Treatment } \\
\text { group }\end{array}$} & \multirow[t]{2}{*}{ Experimental feed } & \multirow{2}{*}{$\begin{array}{c}\begin{array}{c}\text { No. of } \\
\text { broiler birds }\end{array} \\
10\end{array}$} \\
\hline $\mathbf{G}_{1}$ & $\mathrm{G}_{1} \mathrm{R}_{1}$ & & \\
\hline & $\mathrm{G}_{1} \mathrm{R}_{2}$ & Basal feed & 10 \\
\hline & $\mathrm{G}_{1} \mathrm{R}_{3}$ & Basal feed & 10 \\
\hline & $\mathrm{G}_{1} \mathrm{R}_{4}$ & Basal feed & 10 \\
\hline \multirow[t]{4}{*}{$\mathbf{G}_{\mathbf{2}}$} & $\mathrm{G}_{2} \mathrm{R}_{1}$ & Basal feed + Peppermint $(0.5 \%)$ & 10 \\
\hline & $\mathrm{G}_{2} \mathrm{R}_{2}$ & Basal feed + Peppermint $(0.5 \%)$ & 10 \\
\hline & $\mathrm{G}_{2} \mathrm{R}_{3}$ & Basal feed + Peppermint $(0.5 \%)$ & 10 \\
\hline & $\mathrm{G}_{2} \mathrm{R}_{4}$ & Basal feed + Peppermint $(0.5 \%)$ & 10 \\
\hline \multirow[t]{4}{*}{$\mathbf{G}_{3}$} & $\mathrm{G}_{3} \mathrm{R}_{1}$ & Basal feed + Peppermint (1\%) & 10 \\
\hline & $\mathrm{G}_{3} \mathrm{R}_{2}$ & Basal feed + Peppermint (1\%) & 10 \\
\hline & $\mathrm{G}_{3} \mathrm{R}_{3}$ & Basal feed + Peppermint (1\%) & 10 \\
\hline & $\mathrm{G}_{3} \mathrm{R}_{4}$ & Basal feed + Peppermint (1\%) & 10 \\
\hline \multirow[t]{4}{*}{$\mathbf{G}_{4}$} & $\mathrm{G}_{4} \mathrm{R}_{1}$ & Basal feed + Multi enzyme $(0.05 \%)$ & 10 \\
\hline & $\mathrm{G}_{4} \mathrm{R}_{2}$ & Basal feed + Multi enzyme $(0.05 \%)$ & 10 \\
\hline & $\mathrm{G}_{4} \mathrm{R}_{3}$ & Basal feed + Multi enzyme $(0.05 \%)$ & 10 \\
\hline & $\mathrm{G}_{4} \mathrm{R}_{4}$ & Basal feed + Multi enzyme $(0.05 \%)$ & 10 \\
\hline \multirow[t]{4}{*}{$\mathbf{G}_{5}$} & $\mathrm{G}_{5} \mathrm{R}_{1}$ & Basal feed + Peppermint $(0.5 \%)+$ Multi enzyme $(0.05 \%)$ & 10 \\
\hline & $\mathrm{G}_{5} \mathrm{R}_{2}$ & Basal feed + Peppermint $(0.5 \%)+$ Multi enzyme $(0.05 \%)$ & 10 \\
\hline & $\mathrm{G}_{5} \mathrm{R}_{3}$ & Basal feed + Peppermint $(0.5 \%)+$ Multi enzyme $(0.05 \%)$ & 10 \\
\hline & $\mathrm{G}_{5} \mathrm{R}_{4}$ & Basal feed + Peppermint $(0.5 \%)+$ Multi enzyme $(0.05 \%)$ & 10 \\
\hline \multirow[t]{4}{*}{$\mathbf{G}_{6}$} & $\mathrm{G}_{6} \mathrm{R}_{1}$ & Basal feed + Peppermint $(1.0 \%)+$ Multi enzyme $(0.05 \%)$ & 10 \\
\hline & $\mathrm{G}_{6} \mathrm{R}_{2}$ & Basal feed + Peppermint $(1.0 \%)+$ Multi enzyme $(0.05 \%)$ & 10 \\
\hline & $\mathrm{G}_{6} \mathrm{R}_{3}$ & Basal feed + Peppermint $(1.0 \%)+$ Multi enzyme $(0.05 \%)$ & 10 \\
\hline & $\mathrm{G}_{6} \mathrm{R}_{4}$ & Basal feed+ Peppermint $(1.0 \%)+$ Multi enzyme $(0.05 \%)$ & 10 \\
\hline
\end{tabular}

Table.2 Effect of peppermint (Mentha arvensis) and multi-enzyme supplementation on carcass traits

\begin{tabular}{|c|c|c|}
\hline Group & Dressed weight & Eviscerated weight \\
\hline $\mathbf{G}_{\mathbf{1}}$ & $77.05^{\mathrm{a}} \pm 0.75$ & $71.18 \pm 1.13$ \\
\hline $\mathbf{G}_{\mathbf{2}}$ & $76.33^{\mathrm{a}} \pm 0.84$ & $70.99 \pm 1.04$ \\
\hline $\mathbf{G}_{\mathbf{3}}$ & $77.39^{\mathrm{ab}} \pm 0.54$ & $70.16 \pm 0.39$ \\
\hline $\mathbf{G}_{\mathbf{4}}$ & $78.88^{\mathrm{abc}} \pm 0.39$ & $72.17 \pm 0.78$ \\
\hline $\mathbf{G}_{\mathbf{5}}$ & $81.02^{\mathrm{c}} \pm 1.34$ & $73.32 \pm 0.58$ \\
\hline $\mathbf{G}_{\mathbf{6}}$ & $80.03^{\mathrm{bc}} \pm 1.11$ & $70.82 \pm 0.93$ \\
\hline
\end{tabular}

Mean with different superscript differ significantly within a column 
Table.3 Mean values of of fals weight ( $\mathrm{g}$ ) in different treatment groups

\begin{tabular}{|c|c|c|c|c|}
\hline Groups & Heart & Liver & Gizzard & Giblet \\
\hline G1 & $8.48 \pm 0.44$ & $42.35 \pm 2.72$ & $34.80^{\mathrm{b}} \pm 1.55$ & $85.64 \pm 4.55$ \\
\hline G2 & $9.86 \pm 1.62$ & $52.33 \pm 3.76$ & $26.46^{\mathrm{a}} \pm 2.17$ & $88.66 \pm 7.16$ \\
\hline G3 & $10.32 \pm 1.11$ & $50.18 \pm 3.67$ & $31.70^{\mathrm{ab}} \pm 1.11$ & $92.21 \pm 5.63$ \\
\hline G4 & $9.77 \pm 1.11$ & $46.39 \pm 6.30$ & $34.44^{\mathrm{b}} \pm 0.64$ & $90.61 \pm 7.57$ \\
\hline G5 & $9.45 \pm 0.42$ & $48.43 \pm 2.35$ & $36.25^{\mathrm{b}} \pm 2.60$ & $94.15 \pm 1.22$ \\
\hline G6 & $9.40 \pm 0.84$ & $40.65 \pm 2.61$ & $31.50^{\mathrm{ab}} \pm 3.02$ & $81.56 \pm 2.24$ \\
\hline
\end{tabular}

Mean with different superscript differ significantly within a column

\section{Giblet and of fals weight}

The average weight (g) of Heart, liver, gizzard and giblet of broiler chickens in different treatment groups are presented in table 3.

The effect of supplementation of different levels of peppermint (Mentha arvensis) and multi-enzyme on average weight of Heart, Liver and giblet was non-significant $(\mathrm{P}>0.05)$ in different treatment groups of broiler chicken. However, there was significant $(\mathrm{P}<0.05)$ difference were observed in the average weight of Gizzard in different groups of broiler chicken with highest weight in $\mathrm{G}_{5}$ followed by $\mathrm{G}_{1}, \mathrm{G}_{4}, \mathrm{G}_{3}, \mathrm{G}_{6}$ and least weight was observed in $G_{2}$ group. There was no significant difference between $\mathrm{G}_{3}$ and $\mathrm{G}_{6}$ groups.

The results are supported by Arab Ameri et al., (2016) who reported that the chicks fed diet supplemented with $1 \%$ peppermint powder had significant difference in gizzard weight. Similarly, Ismail et al., (2019) also revealed highly significant difference in gizzard weight percentage in dietary treatment groups fed thyme and its essential oils compared to the control.

In support of present result, Khursheed et al., (2017) revealed no significant $(\mathrm{P}>0.05)$ difference in the characteristics of giblets, viz. heart weight and liver weight among different treatment groups. Abdel-wareth et al., (2019) revealed that inclusion of different concentrations of peppermint leaves or menthol levels had no significant effect $(\mathrm{P}>0.05)$ on the relative weights of liver, heart, gizzard when compared to the control diet at day 35 .

The result of enzyme supplementation showed non-significant difference in gizzard weight, which was not in accordance to the finding of Khan et al., (2006) who revealed significant difference in gizzard weight on dietary supplementation of enzyme in the broiler diet. The effect of multi-enzyme on giblet weight was non-significant which are in agreement with findings of Hussein et al., (2019), Hajati (2010) and Bharathidhasn et al., (2009) who found no significant differences among the treatments in term of giblet weights. Nizamuddin et al., (2013) revealed that dietary supplementation of mixed enzyme irrespective of various levels could not reflect any significant difference on weights of giblets. Khursheed et al., (2017) did not observe any significant difference in giblet weight compared to control.

The combination of peppermint and multienzyme showed non-significant difference in giblet weight which is in accordance to finding of Khursheed et al., (2017) who reported non-significant $(\mathrm{P}>0.05)$ difference in giblet weight on supplementation of enzyme treated mint leaves to broiler chicken. 
It is concluded that the use of peppermint at 0.5 and $1.0 \%$ levels and multi-enzyme at $0.05 \%$ levels and their combination improved the carcass weight and other carcass traits in the broiler chickens.

\section{Acknowledgements}

The author appreciatively acknowledges theVice Chancellor of Rajasthan University of Veterinary and Animal Science (Rajuvas, Bikaner) and Dean Post-Graduate Institute of Veterinary Education and Research, Jaipur, for providing the necessary funds and facilities to conduct of this research.

\section{References}

Abbas, W., S. H. Khan and M. Sarwar. 1998. Sunflower oil meal as a substitute for soybean meal in broiler ration with or without multi-enzyme (Kenzyme). Pakistan Veterinary Journal. 18:124-129.

Abouelfetouh, A. Y. and Moussa, N. K. 2012. Enhancement of antimicrobial activity of four classes of antibiotics combined with garlic. Asian Journal of Plant Sciences, 11(3), 148.

Adil, S, Qureshi S. and Pattoo R.A. 2015. A review on positive effects of fenugreek as feed additive in poultry production. International Journal Poultry Science. 14 (12): 664-669.

Applegate, T. J., B. C. Joern, D. L. NussbaumWaglerand Angel, R. 2003. Water-soluble phosphorus in fresh broiler litter is dependent upon phosphorus concentration fed but not on fungal phytase supplementation. Poultry Science. 82: 1024-1029.

Bali, S.K.D., Anupam, K.Dipanwita P, Biswas S, Bhattacharyya D. 2011. A Comparative Study on the Antioxidant and Antimicrobial Properties of Garlic and Coriander on Chicken Sausage. International Journal of Meat Science, 108-116.

Bharathidhasan, A., Chandrasekaran, D., Natarajan, A., Ravi, R. and Ezhilvalavan, S. 2009. Effect of enzyme supplementation on carcass quality, intestinal viscosity and ileal digestabilities of broilers to nutrient reduced diet. Tamilnadu Journal of Veterinary and Animal Sciences, 5(6), 239-245. BIS. 1992. Bureau of indian standards.

Brenes, A., Centeno, C., Viveros, A. and Arija, I. 2008. Effect of enzyme addition on the nutritive value of high oleic acid sunflower seeds in chicken diets. Poultry Science, 87(11), 2300-2310.

Duncan., D.B. 1955. Multiple range and multiple F tests. Biometrics, 11:1-42.

Durrani, F. R., Abidullah, N. C., Durrani, Z. and Akhtar, S. 2008. Hematological, biochemical, immune modulatory and growth promoting effect of feed added wild mint (Mentha longifolia) in broiler chicks. Sarhad Journal of Agriculture, 24(4), 661-665.

Fadlalla, I. M. T., Mohammed, B. H., and Bakhiet, A. O. 2010.Effect of feeding garlic on the performance and immunity of broilers. Asian Journal of Poultry Science, 4(4), 182-189.

FAO (2007). The Food and Agriculture Organization.

Galib A.M. Al-Kassie 2010. The role of peppermint (Mentha piperita) on performance in broiler diets. Agriculture and Biology Journal of North America 1(5): 1009-1013.

Ghazaghi, M., Mehria, M. and Bagherzadeh, K, F. 2014.Effects of dietary Menthaspicata on performance, blood metabolites, meat quality and microbial ecosystem of small intestine in growing Japanese quail. Animal Feed Science and Technology. 194: 89-98.

Hafeez, A., Männer, K., Schieder, C. and Zentek, J. 2016. Effect of supplementation of phytogenic feed additives (powdered vs. encapsulated) on performance and nutrient digestibility in broiler chickens. Poultry science, 95(3), 622-629.

Hajati, H. (2010). Effects of enzyme supplementation on performance, carcass characteristics, carcass composition and some blood parameters of broiler chicken. American Journal of Animal and Veterinary Sciences, 5(3), 221-227.

Ismail, F. S. A., El-Gogary, M. R., and El-Morsy, M. N. 2019.Impact of dietary 
supplementation of different levels of thyme and its essential oils on performance, blood parameters, metabolic and immune response of broiler chickens. Egyptian Poultry Science Journal, 39(2), 365-379.

Khan SW, Khatoon S. 2008. Ethan botanical studies on some useful herbs of Haramosh and Bugrote Valleys in Gilgit, Pakistan Journal of Botany, 40(1): 43-58.

Khempaka, S., Pudpila, U. and Molee, W. 2013.Effect of dried peppermint (Menthacordifolia) on growth performance, nutrient digestibility, carcass traits, antioxidant properties, and ammonia production in broilers. The Journal of Applied Poultry Research, 22(4), 904-912.

Khursheed, A., Banday, M. T., Khan, A. A., Adil, S., Ganai, A. M., Sheikh, I. U. and Sofi, A. H. 2017. Effect of mint leaves with or without enzyme supplementation on blood biochemistry, carcass characteristics and sensory attributes of broiler chicken. Advance Animal Veterinary Science, 5(11), 449-455.

Leytem, A. B and P. W. Plumstead, R. O. Maguire, P. Kwanyuen, J. Brake. 2007. what aspect of dietary modification in broilers controls litter water-soluble phosphorus: Dietary phosphorus, phytase, calcium. Journal of Environment Quality. 36:453-463.

Londonkar R.L. and Poddar P.V. 2009. Studies on activity of various extracts of Mentha arvensis linn against drug induced gastric ulcer in mammals. World Journal Gastrointestinal Oncology. 15(1):82-88.

Nizamuddin, A. A., Vidyarthi, V. K. and Sharma,
V. B. 2013. Performance of broiler chicken fed on diets supplemented with mixed enzyme. Indian Journal of Poultry Science 48(2), 250-253.

Panda, P.C. 1995.Slaughtering techniques. In: Text book on Egg and Poultry Technology, Vikas Publications, New Delhi, India.

Reverter, M., Bontemps, N., Lecchini, D., Banaigs, B. and Sasal, P. 2014. Use of plant extracts in fish aquaculture as an alternative to chemotherapy: Current status and future perspectives. Aquaculture, 433, 50-61.

Selle, P. H., Ravindran, V. and Partridge, G. G. 2009. Beneficial effects of xylanase and/or phytase inclusions on ileal amino acid digestibility, energy utilization, mineral retention and growth performance in wheatbased broiler diets. Animal Feed Science and Technology, 153(3-4), 303-313.

Wang, J. P., Hong, S. M., Y. L., Yoo, J. S., Lee, J. H., Jang, H. D. and Kim, I. H. 2009. Effects of single or carbohydrases cocktail in lownutrient-density diets on growth performance, nutrient digestibility, blood characteristics, and carcass traits in growing-finishing pigs. Livestock Science, 126(1-3), 215-220.

Younis, Y.M.H. Beshir, S.M. 2004. Carvone-rich essential oils from Mentha longifolia (L.) Huds.ssp. schimperibriq and

Zhou Y, Jiang Z, Lv D. and WangT. 2009. Improved energy utilizing efficiency by enzyme preparation supplement in broiler diets with different metabolizable energy levels.Poultry Science.88:316-322.

\section{How to cite this article:}

Amit Kumar Lavania, Sheela Choudhary, Anurag Pandey, Manju, Dharmendra Chharang, Khushiram Yadav and Vijay Prakash Saini. 2020. Effect of Peppermint and Multi-enzyme Supplementation on the Carcass Characteristics in the Broiler Chickens. Int.J.Curr.Microbiol.App.Sci. 9(09): 584-591. doi: https://doi.org/10.20546/ijcmas.2020.909.074 